\title{
Role for dnaK locus in tolerance of multiple stresses in Staphylococcus aureus
}

Correspondence
V. K. Singh
vsingh@atsu.edu

Received 13 February 2007

Revised 3 May 2007

Accepted 9 May 2007

\author{
Vineet K. Singh, ${ }^{1}$ Sugunya Utaida, ${ }^{2}$ † Letitia S. Jackson, ${ }^{1}$ R. K. Jayaswal, ${ }^{2}$
} Brian J. Wilkinson ${ }^{2}$ and Neal R. Chamberlain ${ }^{1}$

\author{
${ }^{1}$ Microbiology and Immunology, A. T. Still University of Health Sciences, Kirksville, MO 63501, USA \\ ${ }^{2}$ Microbiology Group, Department of Biological Sciences, Illinois State University, Normal, \\ IL 61790, USA
}

\begin{abstract}
Heat-shock proteins are essential for stress tolerance and allowing organisms to survive conditions that cause protein unfolding. The role of the Staphylococcus aureus DnaK system in tolerance of various stresses was studied by disruption of $d n a K$ by partial deletion and insertion of a kanamycin gene cassette. Deletion of dnaK in $S$. aureus strain COL resulted in poor growth at temperatures of $37{ }^{\circ} \mathrm{C}$ and above, and reduced carotenoid production. The mutant strain also exhibited increased susceptibility to oxidative and cell-wall-active antibiotic stress conditions. In addition, the mutant strain had slower rates of autolysis, suggesting a correlation between DnaK and functional expression of staphylococcal autolysins. Deletion of $d n a K$ also resulted in a decrease in the ability of the organism to survive in a mouse host during a systemic infection. In summary, the DnaK system in $S$. aureus plays a significant role in the survival of $S$. aureus under various stress conditions.
\end{abstract}

\section{INTRODUCTION}

Staphylococcus aureus is an aggressive pathogen that is responsible for a wide array of diseases ranging from pyogenic skin infections to complicated life-threatening diseases, such as bacteraemia, central nervous system infections, endocarditis, osteomyelitis, pneumonia, septicaemia, septic arthritis, urinary tract infections, and chronic lung infections associated with cystic fibrosis (Lyczak et al., 2002; Projan \& Novick, 1997). Additionally, toxigenic strains of $S$. aureus are responsible for diseases such as toxic shock syndrome and scalded skin syndrome (Projan \& Novick, 1997). Of additional concern, the organism is resistant to most available antibiotics, and there are very limited therapeutic options for the treatment of staphylococcal infections (Bal \& Gould, 2005; Chopra, 2003; Cui et al., 2006; Schito, 2006).

Heat-shock proteins (Hsps) that are molecular chaperones play important roles in bacterial stress tolerance. The molecular genetics and expression of these conserved Hsps have been most extensively studied in Escherichia coli and Bacillus subtilis. In E. coli, expression of Hsps is regulated by the alternative sigma factor $32\left(\sigma^{32}\right)$, which is encoded by the rpoH gene (Mogk et al., 1999; Yura et al., 2000). Hsps provide major protection against cytoplasmic protein damage. In addition to $\sigma^{32}$ in E. coli, an alternative sigma

tPresent address: Department of Biotechnology, Thammasat University, Pathum Thaini 12121, Thailand.

Abbreviation: Hsp, heat-shock protein. factor, $\sigma^{\mathrm{E}}$, also protects proteins from misfolding in the extracytoplasmic compartment under extreme heat stress (Yura et al., 2000).

In Bac. subtilis, at least four classes of Hsps have been identified based on their regulatory mechanisms. Class I Hsps comprise the classical Hsps that are encoded by genes of the groES/EL and dnaK operons, and cellular levels of these proteins are controlled by the HrcA repressor (Schulz \& Schumann, 1996). Class II Hsps are $\sigma^{\mathrm{B}}$ dependent, and are induced by heat and other stresses (Schulz \& Schumann, 1996). Class III Hsps are Clp proteases/ ATPases, and are typically under the control of the transcriptional repressor CtsR (Derre et al., 1999). The class IV Hsps are encoded by genes that are not controlled by HrcA, $\sigma^{\mathrm{B}}$ or CtsR (Helmann et al., 2001).

In S. aureus, the Hsp100/Clp ATPases have been extensively studied in recent years, and they have been shown to play important roles in stress tolerance, intracellular replication in eukaryotic epithelial cells, biofilm formation, expression of extracellular toxins, and pathogenicity in a murine model of infection (Chatterjee et al., 2005; Frees et al., 2003, 2004; Michel et al., 2006). Surprisingly, in contrast, the $S$. aureus GroES/EL and DnaK proteins have not been studied to this depth. DnaK and GroES/GroEL belong to a family of Hsps found in all organisms (Craig, 1985); these Hsps have been highly conserved during evolution, indicating their important role in cellular metabolism (Maguire et al., 2002). These Hsps are molecular chaperones and proteases that are synthesized in elevated 
amounts during sublethal heat and other stress conditions. They prevent misfolding and aggregation of proteins, and promote their refolding and proper assembly under normal and stress conditions (Checa \& Viale, 1997; Craig, 1985; Diamant \& Goloubinoff, 1998; Hartl, 1996; Hubbard \& Sander, 1991; Walter \& Buchner, 2002). The Hsps bind and release hydrophobic segments of an unfolded polypeptide chain in an ATP-hydrolytic reaction cycle (Hartl, 1996; Walter \& Buchner, 2002).

Several studies have indicated an altered expression of staphylococcal GroEL and DnaK homologues under various environmental growth conditions (Qoronfleh et al., 1990). These proteins are induced during infection of epithelial cells under conditions that do not involve thermal stress (Qoronfleh et al., 1998), suggesting involvement of these proteins in the infection process. Additionally, sera from endocarditis patients have antibodies against these Hsps (Qoronfleh et al., 1993). These Hsps have also assumed significance in antibiotic action, as they are induced under cell-wall-active antibiotic stress in S. aureus (Singh et al., 2001a; Utaida et al., 2003).

S. aureus $d n a K$ has been predicted to be part of an operon consisting of at least five genes: $h r c A-g r p E-d n a K-d n a J-$ prmA (Gill et al., 2005; Kuroda et al., 2001; Ohta et al., 1994). This genomic organization is similar to the first five genes of a heptacistronic message observed in Bac. subtilis (Homuth et al., 1997). It has been recently reported that the S. aureus dnaK, as well as the groEL operon, are subjected to dual negative regulation by CtsR and HrcA (Chastanet et al., 2003). However, S. aureus is able to overcome this repression during growth at higher temperatures and in other stress conditions (Chastanet et al., 2003). Beyond these studies, the roles of proteins encoded by the dnaK locus in S. aureus physiology are poorly understood. To begin to elucidate these roles, a knockout mutant of the dnaK gene in S. aureus was constructed. The findings of this study suggest critical roles for the staphylococcal dnaK locus in protection from heat, oxidative and antibiotic stress, in autolysis and pigmentation, and in survival in a mouse host.

\section{METHODS}

Bacterial strains, plasmids and growth conditions. The bacterial strains and plasmid constructs used in this study are shown in Table 1. S. aureus and E. coli cells were routinely grown aerobically at $37{ }^{\circ} \mathrm{C}$ in tryptic soy broth/agar (TSB/TSA; Beckton Dickinson) and LuriaBertani broth/agar, respectively. Broth cultures were grown in a shaking incubator (250 r.p.m.), unless stated otherwise. When needed, ampicillin $\left(50 \mu \mathrm{g} \mathrm{ml}^{-1}\right)$, kanamycin $\left(30 \mu \mathrm{g} \mathrm{ml}^{-1}\right.$ for E. coli; $100 \mu \mathrm{g} \mathrm{ml}^{-1}$ for $S$. aureus) and chloramphenicol $\left(10 \mu \mathrm{g} \mathrm{ml}^{-1}\right)$ were added to the growth medium.

DNA isolation and manipulations. Plasmid DNA was isolated using the Qiaprep kit (Qiagen); chromosomal DNA was isolated using DNAzol kit (Molecular Research Center) from lysostaphintreated S. aureus cells, as per the manufacturer's instructions. All restriction and modification enzymes were purchased from Promega. DNA manipulations, and Southern blot and Northern blot analyses, were carried out using standard procedures. PCR was performed with the GeneAmp PCR system (Perkin-Elmer). Oligonucleotide primers were obtained from Integrated DNA Technology.

Construction of a dnaK mutant in S. aureus. To create a dnaK mutant, primers P1 (5'-GCTGTAGTTCAAGATGATAACCC- $\left.3^{\prime}\right)$ and P2 (5'-CAGAGCCATTGAATCCTTGTC- $\left.3^{\prime}\right)$ were used to amplify a

Table 1. Bacterial strains and plasmids used in this study

\begin{tabular}{|c|c|c|}
\hline Strain or plasmid & Characteristics & Reference \\
\hline S. aureus $8325-4$ & A laboratory strain of $S$. aureus cured of all the prophages & Novick (1991) \\
\hline S. aureus $\mathrm{SH} 1000$ & S. aureus strain $8325-4$ with functional $r s b U$ & Horsburgh et al. (2002) \\
\hline COL:dnaK & S. aureus COL with mutation in the dnaK gene $\left(\operatorname{Kan}^{\mathrm{R}}\right)$ & This study \\
\hline SH1000:dnaK & S. aureus $\mathrm{SH} 1000$ with mutation in the dnaK gene $\left(\operatorname{Kan}^{\mathrm{R}}\right)$ & This study \\
\hline E. coli JM109 & $\begin{array}{l}\text { recA1 supE44 endA1 hsdR17 gyrA96 relA1 thi } \Delta\left(\text { lac-proAB) } \mathrm{F}^{\prime}\right. \\
\left(\text { traD36 proAB }{ }^{+} \text {lacl }{ }^{\mathrm{A}} \Delta \mathrm{M} 15\right)\end{array}$ & Yanisch-Perron et al. (1985) \\
\hline \multicolumn{3}{|c|}{${ }^{\prime}$} \\
\hline pGEMT & Cloning vector for E. coli $\left(\mathrm{Amp}^{\mathrm{R}}\right)$ & Promega \\
\hline pCR2.1 & Cloning vector for E. coli $\left(\mathrm{Amp}^{\mathrm{R}}, \mathrm{Kan}^{\mathrm{R}}\right)$ & Invitrogen \\
\hline pTZ18R & Cloning vector for E. coli $\left(\mathrm{Amp}^{\mathrm{R}}\right)$ & Mead et al. (1986) \\
\hline pCU1-dnaK & $6.4 \mathrm{~kb}$ fragment containing all five genes of the $d n a K$ locus & This study \\
\hline
\end{tabular}

${ }^{\star}$ Most cells in the population of homogeneous strains grow in the presence of high concentrations of meticillin (Sutherland \& Rolinson, 1964). 
2.4 kb DNA fragment, using chromosomal DNA from $S$. aureus strain $\mathrm{COL}$ as the template. The amplicon encompassing the entire $d n a K$ gene, $164 \mathrm{bp}$ upstream, and $391 \mathrm{bp}$ downstream, was cloned into plasmid pCR2.1 (Invitrogen). A HindIII fragment of approximately $2.2 \mathrm{~kb}$ was excised from this construct, and subcloned into the vector pTZ18R (Mead et al., 1986). A 432 bp DNA fragment was excised from the resultant construct pTZ18R-dnaK by digestion with EcoRV, and replaced with a $1.4 \mathrm{~kb}$ kanamycin-resistance cassette (Gutierrez et al., 1996). The vector pTZ18R cannot replicate in Gram-positive bacteria, and the plasmid-disrupted dnaK construct pTZ-dnaK-kan was used as a suicide vector to transform S. aureus strain RN4220 via electroporation (Schenk \& Laddaga, 1992). The transformants were selected on TSA plates containing kanamycin. The selection resulted in a single crossover, and integration of the entire construct into the $S$. aureus chromosome. Phage $80 \alpha$ was propagated on these transformants, and used to resolve the mutation in the $d n a K$ gene in $S$. aureus by performing transduction outcrosses, as described previously (Singh \& Moskovitz, 2003; Singh et al., 2001b). The transductants were confirmed for a mutation in the dnaK gene using PCR and Southern blotting. For genetic complementation of the dnaK mutant, a $6.4 \mathrm{~kb}$ DNA fragment was PCR amplified using primers P5 (5'-GGTACCTTCTTTGACTGAGAGAATGG-3') and P6 (5'-TCTAGAGCAACCACTCATATTTGTCA-3'), S. aureus COL genomic DNA as a template, and EXL DNA Polymerase (Stratagene). Restriction sites (underlined) were included in the primers to facilitate subcloning of the amplified fragments. The amplicon represents a fragment starting $340 \mathrm{nt}$ upstream of the $h r c A$ gene and 285 nt downstream of the prmA gene that was cloned to the KpnI and XbaI sites of a shuttle plasmid pCU1 (Augustin et al., 1992), and subsequently transferred to the dnaK mutant of $S$. aureus strain COL.

Growth kinetics of the wild-type $S$. aureus and its isogenic dnaK mutant under stress. Mid-exponential-phase cultures $\left(\mathrm{OD}_{600}\right.$ 0.6 ) were diluted 50 -fold in a nephelo culture flask (Wheaton) containing $50 \mathrm{ml}$ fresh TSB, with a flask-to-medium volume ratio of $6: 1$. In parallel flasks, the following stress conditions were imposed through appropriate modifications of TSB: $8.8 \mathrm{mM} \mathrm{H}_{2} \mathrm{O}_{2}, 4 \%(\mathrm{v} / \mathrm{v})$ ethanol, low $\mathrm{pH}(\mathrm{pH} 4.5)$, high $\mathrm{pH}(\mathrm{pH} 10.0)$ and $\mathrm{NaCl}(2.5 \mathrm{M})$. Growth was then followed by measurement of $\mathrm{OD}_{600}$ spectrophotometrically. These stress conditions were chosen based on prior studies (Singh \& Moskovitz, 2003; Singh et al., 2001a, 2001b; Utaida et al., 2003), or on pilot studies where significant growth inhibition was observed for wild-type bacteria.

Viability and thermotolerance of $\boldsymbol{S}$. aureus exposed to different stresses. For induction of thermotolerance, mid-exponential-phase cultures $\left(\mathrm{OD}_{600} 0.6\right)$ were diluted 50 -fold in fresh TSB, and placed at $37{ }^{\circ} \mathrm{C}$ until the $\mathrm{OD}_{600}$ reached 0.3 . The cultures were then divided into two parts, and one was maintained at $37{ }^{\circ} \mathrm{C}$, while the other was incubated at $48{ }^{\circ} \mathrm{C}$ for $30 \mathrm{~min}$. Both flasks were then shifted to $60{ }^{\circ} \mathrm{C}$, and after 0,5 , and $10 \mathrm{~min}$, aliquots of the cultures were quickly transferred to ice, diluted in TSB, plated on TSA, incubated at $37^{\circ} \mathrm{C}$ for $48 \mathrm{~h}$, and counted for viable colonies.

Determinations of susceptibility of the dnaK mutant to antibiotics and $\mathbf{H}_{\mathbf{2}} \mathbf{O}_{\mathbf{2}}$. The MICs for the wild-type and the dnaK mutant of $S$. aureus strain COL were determined as described (Pfeltz et al., 2000), using 96-well microtitre plates containing twofold serial dilutions of oxacillin, meticillin and $\mathrm{H}_{2} \mathrm{O}_{2}$. Mid-exponential-phase wild-type and dnaK mutant staphylococcal cells were then added to these dilutions, to a final concentration of $5 \times 10^{5}$ c.f.u. $\mathrm{ml}^{-1}$. The plates were incubated at $37{ }^{\circ} \mathrm{C}$ for $48 \mathrm{~h}$, and the lowest concentration of antibiotic or $\mathrm{H}_{2} \mathrm{O}_{2}$ with no apparent visible growth was considered to be the MIC.

RNA extraction and Northern hybridization. An overnight culture of S. aureus strain COL was diluted 100-fold in TSB, and grown at
$37{ }^{\circ} \mathrm{C}$ until the $\mathrm{OD}_{600}$ reached 0.3 . The cultures were divided into four parts, and subjected to various stress conditions. For heat stress, the culture was shifted to $43{ }^{\circ} \mathrm{C}$. Oxacillin stress was imposed by the addition of this antibiotic at a final concentration of $1.2 \mathrm{mg} \mathrm{ml}^{-1}$. Oxidative stress was imposed by the addition of $\mathrm{H}_{2} \mathrm{O}_{2}$ to a final concentration of $15 \mathrm{mM}$. The control culture was maintained at $37^{\circ} \mathrm{C}$. Cultures were stressed for $10 \mathrm{~min}$. Bacterial cells were harvested by centrifugation, resuspended in $1.0 \mathrm{ml}$ RNAlater (Ambion), and incubated overnight at $4{ }^{\circ} \mathrm{C}$ to inactivate RNases. Cells were washed with PBS, recovered by centrifugation, resuspended in $1.0 \mathrm{ml}$ RNA-Bee (Tel-Test), and broken using $0.1 \mathrm{~mm}$ silica/ zirconium beads in a BioSpec Mini-Beadbeater by subjecting the cell suspension to three cycles of bead beating $(30 \mathrm{~s}$ each, with $1 \mathrm{~min}$ breaks of cells on ice). The method was adapted from a procedure to extract RNA from Mycobacterium tuberculosis cells, as described (Talaat et al., 2002). Total RNA was chloroform extracted from the cell-free supernatant, and precipitated by the addition of 2-propanol $(50 \% \mathrm{v} / \mathrm{v})$. The resulting RNA was treated with DNase I (Ambion), and purified by affinity chromatography using the RNeasy kit (Qiagen). Subsequently, equal amounts of RNA $(10 \mu \mathrm{g})$ from each sample were separated during $1.2 \%$ denaturing agarose gel electrophoresis, and transferred to a nylon membrane. The $6.4 \mathrm{~kb}$ DNA fragment from the construct $\mathrm{pCU}-d n a K$ was gel purified, radiolabelled using the Prime-a-Gene labelling system (Promega) in the presence of $\left[\alpha_{-}{ }^{32} \mathrm{P}\right] \mathrm{dATP}$ [specific activity $>3000 \mathrm{Ci} \mathrm{mmol}^{-1}$ $\left(>111 \mathrm{TBq} \mathrm{mmol}^{-1}\right)$; MP Biochemicals], and used to probe the membrane. The scanned Northern blot as a JPEG image was analysed with ImageJ 1.6 software, which is a public domain Java image processing program (http://rsb.info.nih.gov/ij) (Abramoff et al., 2004)

Persistence of S. aureus strain $\mathrm{SH} 1000$ and its isogenic dnaK mutant during oxacillin treatment. Overnight cultures of the wildtype $S$. aureus strain $\mathrm{SH} 1000$ and its isogenic dnaK mutant were diluted $1: 1000$ in fresh TSB, and incubated at $37^{\circ} \mathrm{C}$ with shaking (150 r.p.m.) to an $\mathrm{OD}_{600}$ of 0.5 . Both cultures were subsequently treated for $16 \mathrm{~h}$ at $37^{\circ} \mathrm{C}$ with $10 \mu \mathrm{g}$ oxacillin $\mathrm{ml}^{-1}$. Total viable counts in both cultures before and after oxacillin treatment were performed by serial dilution and plating. The surviving fraction was calculated by dividing the number of viable organisms subsequent to oxacillin treatment by the number of viable organisms before antibiotic treatment.

Whole-cell autolysis assays. Autolysis assays were performed as previously described (Pfeltz et al., 2000). Briefly, wild-type and dnaK mutant cultures of $S$. aureus $\mathrm{COL}$ were grown to an $\mathrm{OD}_{600}$ of 1.0 at $37{ }^{\circ} \mathrm{C}$ in PYK medium $(0.5 \%$ bacto peptone, $0.5 \%$ yeast extract, $0.3 \% \mathrm{~K}_{2} \mathrm{HPO}_{4}, \mathrm{pH} 7.2$ ). After one wash with cold water, cells were resuspended to an initial density of 1.2 in $0.05 \mathrm{M}$ Tris/HCl buffer, $\mathrm{pH} 7.2$, containing $0.05 \%$ Triton X-100. The flasks were incubated at $37{ }^{\circ} \mathrm{C}$ with shaking (150 r.p.m.), and subsequent readings were taken every $30 \mathrm{~min}$ for $6 \mathrm{~h}$.

Carotenoid production in wild-type $S$. aureus and its isogenic dnaK mutant. Overnight cultures $(5.0 \mathrm{ml})$ were pelleted by centrifugation, and the pellets were washed twice in $5.0 \mathrm{ml}$ sterile water. The final supernatant was removed, and the pellets were then weighed. The pigments were extracted with methanol, as described (Marshall \& Wilmoth, 1981). The volume of the final carotenoid-containing extract from $0.25 \mathrm{~g}$ of cells was placed in petroleum ether, and the $A_{462}$ was obtained with a Beckman DU-70 spectrophotometer.

Survival of the wild-type and the dnaK mutants in a murine systemic infection model. Wild-type $S$. aureus strain COL and its isogenic dnaK mutant were grown to mid-exponential phase $\left(\mathrm{OD}_{600}\right.$ $0.6)$ in TSB. Bacterial cells from each culture were harvested by centrifugation, washed three times with $1 \%$ TSB, and resuspended in $1 \%$ TSB. Cell viability in the suspension was determined by serial 
dilution and plating. A mixture of wild-type and dnaK mutant cells, containing a total of $5 \times 10^{8}$ c.f.u. $\mathrm{ml}^{-1}$, was prepared $(76 / 24 \%$ mixture of mutant/wild-type) in $1 \% \mathrm{TSB}$, and $0.2 \mathrm{ml}$ of this suspension was injected into the peritoneal cavity of Swiss white Hla(ICR)CVF female mice (16-20 g) (Hilltop Lab Animals Inc.) with a 26 gauge needle fitted to a $1 \mathrm{ml}$ syringe, following published procedures with appropriate modifications (Schwan et al., 2006). At 4,8 and $30 \mathrm{~h}$, the mice were euthanized by $\mathrm{CO}_{2}$ asphyxiation. The peritoneum was lavaged with $1 \mathrm{ml} 1 \% \mathrm{TSB}$, and the liver and spleen were aseptically removed from the peritoneal cavity. Excised livers and spleens were homogenized in 2 and $1 \mathrm{ml} 1 \%$ TSB, respectively, using a glass tissue grinder fitted with a glass pestle. Peritoneal lavages and the tissue homogenates were serially diluted, plated on TSA, and allowed to grow overnight by incubation at $37^{\circ} \mathrm{C}$. The bacterial colonies were subsequently patched on TSA plates containing kanamycin. The number of bacterial colonies growing in the presence of kanamycin was used to calculate the fraction of dnaK mutants relative to wild-type in the bacterial population in the infected tissues. The ratio of surviving mutant was subsequently compared with the percentage of mutants in the mixed culture used to inject mice.

\section{RESULTS}

\section{Construction of the dnaK mutant}

The genetic organization of the dnaK locus in S. aureus is shown in Fig. 1(a). Altogether, five genes have been proposed to constitute the dnaK cluster in $S$. aureus (Kuroda et al., 2001; Ohta et al., 1994). The first gene of this cluster is proposed to encode a protein HrcA that negatively regulates the expression of the $d n a K$ locus
(Chastanet et al., 2003). A study by others, and nucleotide sequence analysis of the dnaK locus in S. aureus, have suggested the presence of two putative promoters: one upstream of $h r c A$, and another one upstream of $d n a J$ (Ohta et al., 1994). Potential transcription start sites have been mapped for both promoters, suggesting dual regulation of the dnaK locus in S. aureus (Ohta et al., 1994). In the present Northern analysis studies, two transcripts (approx. $5.8 \mathrm{~kb}$ and $3.5 \mathrm{~kb}$ ) hybridized with the gene probe specific to dnaK locus genes (Fig. 2a); this is consistent with a report by others (Ohta et al., 1994). Based on the genetic organization and the findings of Ohta et al. (1994), it was considered that the $5.8 \mathrm{~kb}$ transcript represented a poly-cistronic message with all five genes shown in Fig. 1(a). To construct a mutation, the EcoRV fragment of the dnaK gene was deleted, and replaced by a kanamycin-resistance gene cassette. The mutation was subsequently confirmed by Southern blot analysis (data not shown) and PCR (Fig. 1b). Although the dnaK mutation was constructed in three different strains of $S$. aureus (COL, SH1000 and 8325-4), most experiments described in this study were carried out with the dnaK mutant of strain COL.

\section{DnaK contributes to heat and oxidative stress tolerance}

Comparison of the growth kinetics shows that the growth of the $d n a K$ mutant and the wild-type $S$. aureus in liquid

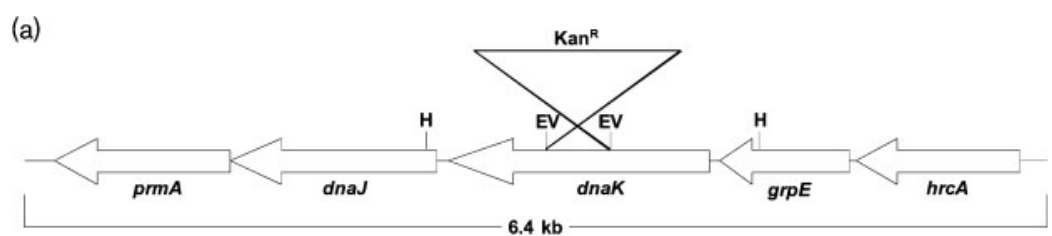

(b)

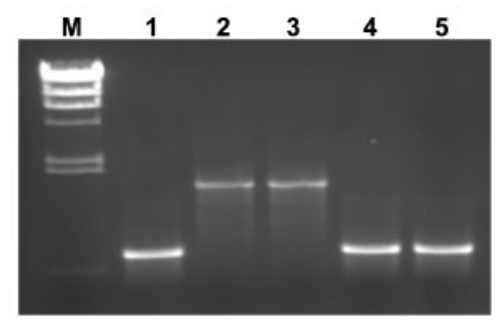

Fig. 1. (a) Diagrammatic representation of the dnaK locus comprising five genes in $S$. aureus. A deletion mutant of this locus was constructed by replacing the EcoRV fragment of the dnaK gene with a $1.4 \mathrm{~kb}$ kanamycin-resistance cassette. The mutant was subsequently complemented in trans with a $6.4 \mathrm{~kb}$ DNA fragment (indicated by arrows). (b) PCR verification of a mutation in the dnaK gene in $S$. aureus. Primers P3 (5'-CCTACACGCCAAGCAATG-3') and P4 (5'-AATACTAGACTGTCAGCTTCGT-3') were used in the PCR that allowed amplification of a $677 \mathrm{bp}$ product (lane 1) when genomic DNA from wild-type $S$. aureus strain COL was used. These primers amplified a fragment of approximately $1.7 \mathrm{~kb}$ when genomic DNA from the dnaK mutant of $S$. aureus strains $\mathrm{SH} 1000$ and COL was used as a template (lanes 2 and 3 , respectively). Lanes 4 and 5, PCR product when genomic DNA from the dnaK mutants of $S$. aureus strains $\mathrm{COL}$ and $\mathrm{SH} 1000$, respectively, were complemented in trans with the $6.4 \mathrm{~kb}$ dnaK locus that was used as a template. The larger PCR product was only faintly visible because of complementation with the wild-type gene on a high-copy plasmid pCU1. M, DNA ladder (Hindlll digest of $\lambda$ DNA). 
(a)

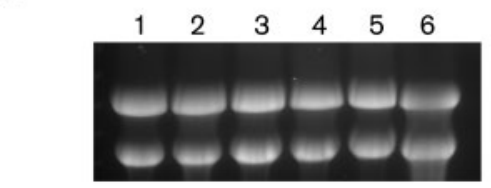

$\mathrm{kb}$
$5.8 \rightarrow$
$3.5 \rightarrow$ (b)

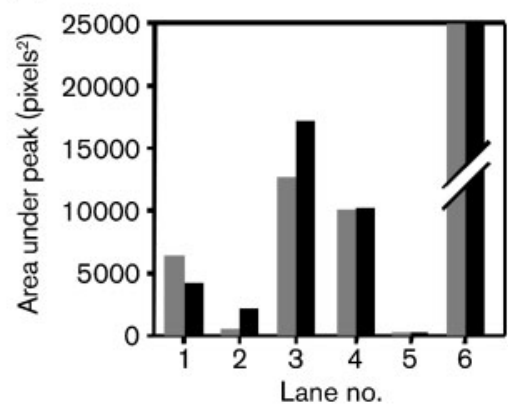

Fig. 2. (a) Northern blot hybridization of the dnaK gene. Total RNA isolated from the cultures of $S$. aureus strain COL was separated on a $1.2 \%$ denaturing agarose gel, as described in Methods, and stained with ethidium bromide to ensure that equivalent amounts of total RNA were present in each lane (top panel). $S$. aureus strain $\mathrm{COL}$ was grown in TSB to an $\mathrm{OD}_{600}$ of 0.3 . The liquid culture was divided into equal volumes in four tubes, and stressed for 10 min before processing for RNA isolation. Lanes: 1, control; 2 and 4, cells stressed with $15 \mathrm{mM} \mathrm{H} \mathrm{H}_{2} \mathrm{O}_{2}$ and $1.2 \mathrm{mg}$ oxacillin $\mathrm{ml}^{-1}$, respectively; 3 , cells exposed to $43{ }^{\circ} \mathrm{C}$. Lanes 5 and 6 , dnaK mutant and mutant complemented with entire dnaK locus on a high-copy plasmid, respectively. Cells were processed using methods similar to those used for the wild-type cells in lane 1. The arrows indicate the transcripts reacting with the probe corresponding to the $6.4 \mathrm{~kb}$ fragment of construct pCU-dnaK. (b) Quantitative data of the intensity of two apparent bands in (a). The $5.8 \mathrm{~kb}$ transcript is shown by the shaded bar, and the $3.5 \mathrm{~kb}$ transcript is shown by the black bar. Lane 6 , both bands were saturated, and the intensity exceeded the scale shown on the $y$-axis; thus, the bands are shown by broken bars. culture was the same at $30{ }^{\circ} \mathrm{C}$ (Fig. 3a) and lower temperatures (data not shown). However, the dnaK mutant showed a longer lag period and slower growth at $37{ }^{\circ} \mathrm{C}$ (Fig. 3b), and failed to grow at $43{ }^{\circ} \mathrm{C}$ (Fig. 3c). The dnaK mutant also showed slower growth when grown on TSA plates at $37{ }^{\circ} \mathrm{C}$. To verify if this was indeed the lack of a functional dnaK gene that impaired its growth at higher temperatures, the dnaK mutant was complemented with the entire dnaK locus in trans on plasmid pCU1. As evident in Fig. 3(c), thermal stress tolerance was partially restored in the complemented strain. This partial restoration of thermal tolerance may be due to complementation of the mutant with the genes of the $d n a K$ locus on a high-copy plasmid leading to higher-than-desired production of the proteins of this locus, which in turn may reduce the growth rate. The response of the $d n a K$ mutant was also tested during its growth under different stress conditions compared with wild-type $S$. aureus. No apparent difference in the growth was observed in the presence of $4 \%(\mathrm{v} / \mathrm{v})$ ethanol, or in acidic ( $\mathrm{pH} 4.5)$, alkaline ( $\mathrm{pH}$ 10.0) or high salt $(2.5 \mathrm{M} \mathrm{NaCl})$ conditions (data not shown). However, in the presence of $8.8 \mathrm{mM} \mathrm{H}_{2} \mathrm{O}_{2}$, the wild-type $S$. aureus was able to grow after a long lag period (Fig. 3d), but the dnaK mutant cells failed to grow after 3 days' incubation. MIC determinations also indicated an eightfold lower $\mathrm{H}_{2} \mathrm{O}_{2} \mathrm{MIC}$ for the dnaK mutant compared with wild-type S. aureus (Table 2).

\section{Involvement of dnaK in induction of thermotolerance}

Mid-exponential-phase cells of the dnaK mutant and its isogenic S. aureus wild-type strain COL were shifted to $60{ }^{\circ} \mathrm{C}$ for a lethal shock, either directly from $37{ }^{\circ} \mathrm{C}$ or after pre-exposure to $48{ }^{\circ} \mathrm{C}$ for $30 \mathrm{~min}$. As shown in Fig. 4 (right), pre-exposure to $48{ }^{\circ} \mathrm{C}$ increased the resistance to lethal heat shock by approximately 1000 -fold after $5 \mathrm{~min}$, and approximately 45 -fold after $10 \mathrm{~min}$ exposure to $60{ }^{\circ} \mathrm{C}$, respectively. However, when untreated dnaK mutant cells were exposed to $60{ }^{\circ} \mathrm{C}$ for 5 or $10 \mathrm{~min}$, no survivor cells were recovered (Fig. 4, left). Pre-exposure to $48{ }^{\circ} \mathrm{C}$ for 30 min helped some of the mutant bacteria survive the lethal shock. In view of this finding, it is suggested that DnaK may have a partial role in the induction of thermotolerance in S. aureus.

\section{Deletion of dnaK decreases oxacillin resistance in meticillin-resistant $S$. aureus strain $\mathrm{COL}$, and persisters in meticillin-susceptible strain SH1000}

Oxacillin resistance in the $d n a K$ mutant was reduced to an MIC of $100 \mu \mathrm{g} \mathrm{ml}^{-1}$ compared with $400 \mu \mathrm{g} \mathrm{ml}^{-1}$ for its isogenic wild-type $S$. aureus strain COL (Table 2). A fourfold reduction in the meticillin MIC was also observed for the dnaK mutant when compared with the wild-type 

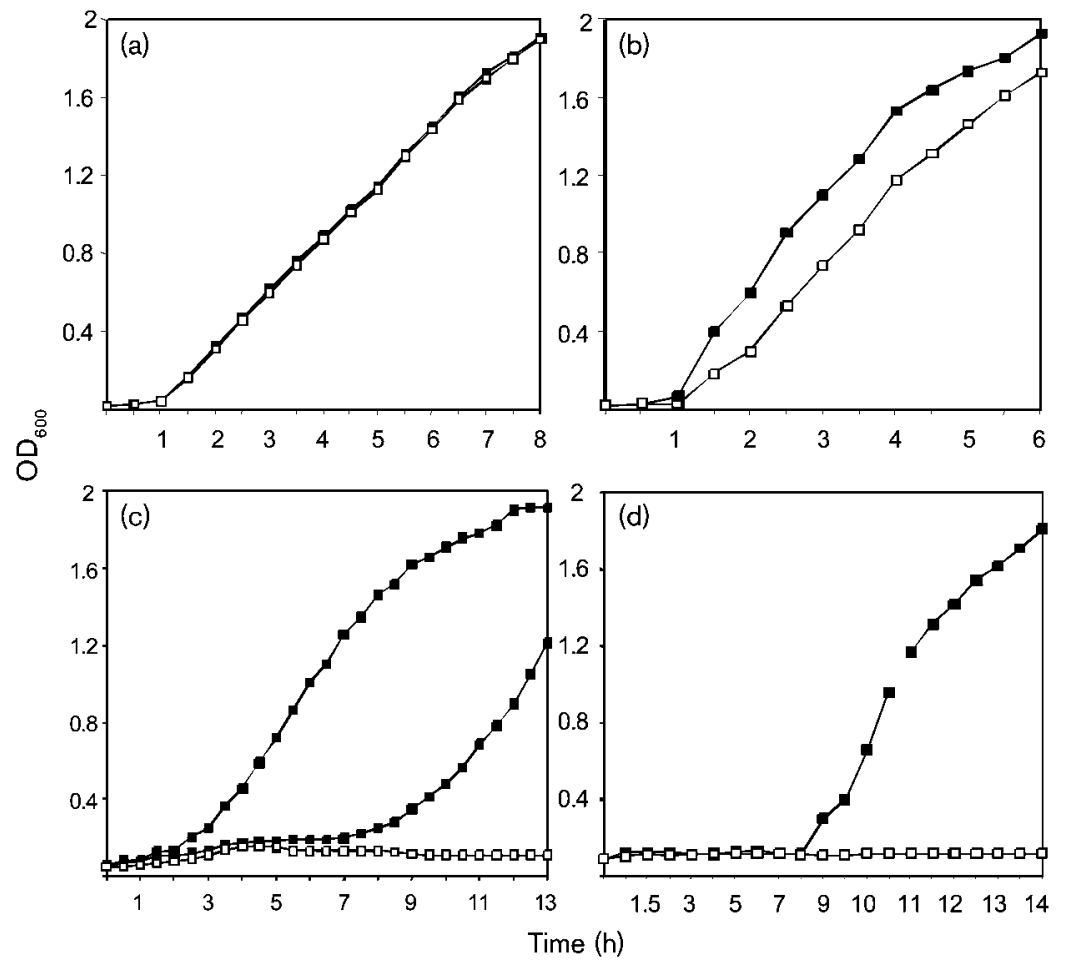

Fig. 3. Growth of the dnaK mutant $(\square)$ and its isogenic wild-type $S$. aureus strain $\mathrm{COL}(\boldsymbol{\square})$. (a) growth at $30{ }^{\circ} \mathrm{C}$; (b) growth at $37^{\circ} \mathrm{C}$; (c) growth at $43{ }^{\circ} \mathrm{C}$, shaded squares represent growth of the mutant complemented with a $6.4 \mathrm{~kb}$ wild-type dnaK fragment on plasmid pCU1; (d) growth in the presence of $8.8 \mathrm{mM}$ $\mathrm{H}_{2} \mathrm{O}_{2}$. Values indicate the mean of two independent experiments.

COL (Table 2). Additionally, in shaking liquid cultures in the presence of oxacillin, growth inhibition was more apparent for the dnaK mutant compared with the wildtype parent strain (Fig. 5a). These results suggest that the lack of a functional DnaK reduces oxacillin and meticillin tolerance in S. aureus. However, no increase in antibiotic susceptibility was observed in the case of meticillinsusceptible S. aureus with a disrupted dnaK locus.

Persistent bacterial cells are a small subset of cells within a bacterial population that are able to survive clinically effective antibiotic concentrations. The persister cells do not contain genetic traits that confer resistance to antibiotics, and, as a result, the progeny of these persisters

Table 2. Susceptibilities of $S$. aureus parental and $d n a K$ mutant strains to oxacillin, meticillin and $\mathrm{H}_{2} \mathrm{O}_{2}$

\begin{tabular}{|lccc|}
\hline \multirow{2}{*}{$\begin{array}{l}\text { Bacterial } \\
\text { strain }\end{array}$} & $\begin{array}{c}\text { MIC } \\
\left(\boldsymbol{\mu} \mathbf{g ~ m}^{-\mathbf{1}}\right)\end{array}$ & $\begin{array}{c}\text { Meticillin } \\
\left(\boldsymbol{\mu} \mathbf{g ~ m}^{-\mathbf{1}}\right)\end{array}$ & $\mathbf{H}_{\mathbf{2}} \mathbf{O}_{\mathbf{2}}(\mathbf{m M})$ \\
\cline { 2 - 4 } & 400 & 800 & 2.0 \\
\hline $\begin{array}{l}\text { S. aureus strain } \\
\text { COL }\end{array}$ & 100 & 200 & 0.25 \\
$\begin{array}{c}\text { COL: dnaK } \\
\text { mutant } \\
\text { Complemented } \\
\text { strain }\end{array}$ & 400 & 800 & 2.0 \\
\hline
\end{tabular}

are just as sensitive to the antibiotic used to treat the parental cells (Korch \& Hill, 2006; Stewart, 2002). Although oxacillin tolerance was reduced in the dnaK mutant of meticillin-resistant $S$. aureus strain COL, no such reduction in the oxacillin MIC was observed in the dnaK mutant of meticillin-susceptible $S$. aureus strain SH1000. The MIC for both strains was determined to be $0.975 \mu \mathrm{g} \mathrm{ml}^{-1}$. In addition, the oxacillin MICs of the wildtype SH1000 and its derivative dnaK mutant survivors after oxacillin treatment in liquid culture did not change. This suggests that the bacteria, though not resistant to the antibiotic, were able to survive oxacillin treatment, albeit at a very low level $(0.54 \%)$. However, when the percentage survival of the persister wild-type and the isogenic dnaK mutant were compared, the mutant had a rate of persistence that was approximately 26-fold lower $(0.021 \%)$ than the wild-type strain.

\section{Whole-cell autolysis of the dnaK mutant}

The effect of mutation in the $d n a K$ gene on autolytic activity was also examined. The autolysis experiments showed a slower rate of autolysis of the $d n a K$ mutant cells compared with wild-type S. aureus strain COL (Fig. 5b). The wild-type $S$. aureus strain COL was more resistant to oxacillin in liquid culture compared with the dnaK mutant, and was able to grow to a higher cell density (Fig. 5a). However, the wild-type $S$. aureus culture started to lyse, and the rate of cell lysis was more pronounced compared with the derivative dnaK mutant cells (Fig. 5a). After 


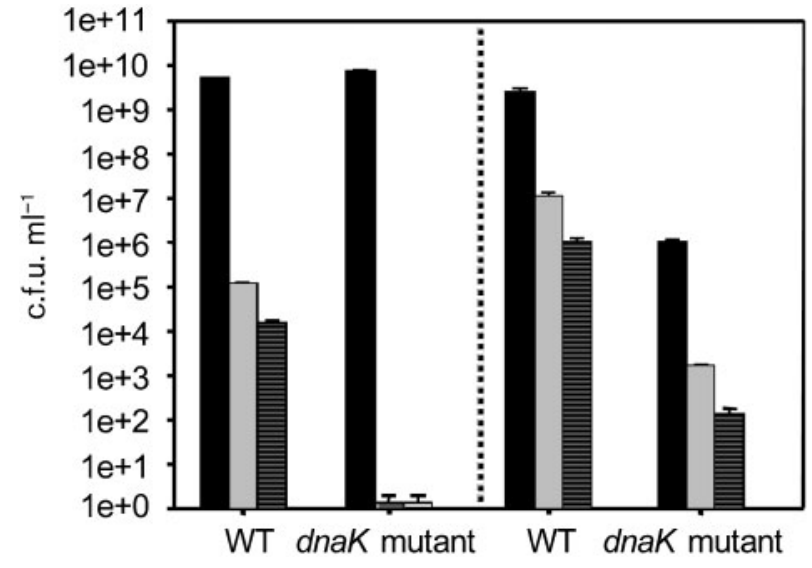

Fig. 4. Survival of the dnaK mutant and its isogenic wild-type $S$. aureus strain $\mathrm{COL}$ to lethal heat stress. Left, cultures were shifted from $37{ }^{\circ} \mathrm{C}$ to $60{ }^{\circ} \mathrm{C}$ for 5 (shaded bars) and $10 \mathrm{~min}$ (bars with horizontal lines); black bars, number of bacteria at $37{ }^{\circ} \mathrm{C}$. Right, cultures were shifted from $48{ }^{\circ} \mathrm{C}$ to $60^{\circ} \mathrm{C}$ for 5 (shaded bars) and $10 \mathrm{~min}$ (bars with horizontal lines); black bars, number of bacteria at $48{ }^{\circ} \mathrm{C}$. Values indicate the mean of three independent experiments. WT, wild-type. Error bars represent SEM.

3 days' incubation, the oxacillin-treated wild-type S. aureus COL culture was completely clear, while the dnaK mutant culture stayed relatively turbid (data not shown). The data suggest altered autolysin production/processing in the dnaK mutant compared with the wild-type $S$. aureus.

\section{Transcriptional analysis of the $S$. aureus dnaK locus}

Comparison of the growth kinetics of the dnaK mutant with wild-type $S$. aureus suggests that DnaK plays a role in the tolerance of heat, oxidative and antibiotic stress. To determine if any of these stress conditions induced the expression of the dnaK gene, Northern blot analysis experiments were carried on total RNA from the control and $S$. aureus cells exposed to these stress conditions. A probe representing the entire $d n a K$ locus genes hybridized with two transcripts of approximately 5.8 and $3.5 \mathrm{~kb}$. Both bands were induced in response to heat and oxacillin stresses (Fig. 2a, lanes 3 and 4; Fig. 2b). An increased production of $d n a K$ locus transcripts in response to heat shock is consistent with an earlier report (Ohta et al., 1994). However, these transcripts were not detected at an elevated level in a more recent global transcription profiling study aimed to characterize the staphylococcal heat shock, cold shock, stringent and SOS responses (Anderson et al., 2006). In the present study also, stress conditions such as oxidative stress had no effect on the expression of $d n a K$ locus genes (Fig. 2a, lane 2; Fig. 2b). As expected, the corresponding bands were absent in the mutant bacteria (Fig. 2a, lane 5; Fig. 2b), but the level of expression of both transcripts was considerably higher in
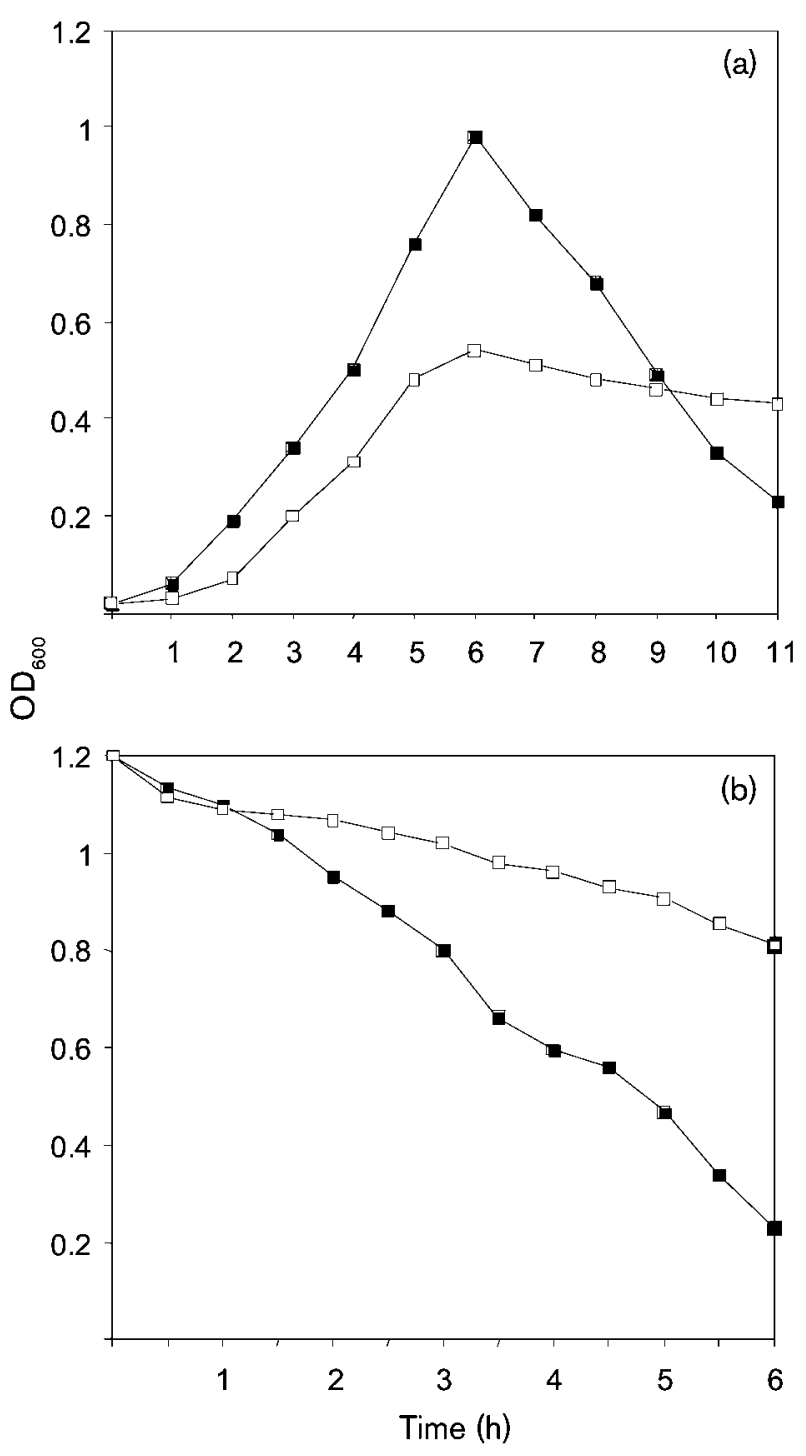

Fig. 5. (a) Growth of the dnaK mutant ( $\square$ ) and its isogenic wildtype $S$. aureus strain COL $(\boldsymbol{\square})$ in the presence of $100 \mu \mathrm{g}$ oxacillin $\mathrm{ml}^{-1}$. (b) Autolysis of the dnaK mutant $(\square)$ compared with autolysis of the isogenic wild-type $S$. aureus strain COL ( $\mathbf{\square})$. Values indicate the mean of two independent experiments.

the case of the mutant complemented with dnaK locus genes on a high-copy plasmid, even under normal growth conditions (Fig. 2a, lane 6; Fig. 2b).

\section{Mutation in dnaK alters pigmentation of the S. aureus cells}

The S. aureus dnaK mutant colonies appeared less pigmented compared with the wild-type COL in broth culture, and during its growth on TSA plates. The S. aureus strain SH1000 produces more pigment than the $S$. aureus strain COL, and the role of dnaK in the production of pigment was more apparent in strain SH1000. In a 
quantitative assay, the wild-type S. aureus strain SH1000 was estimated to produce over threefold more pigment than the $d n a K$ mutant strain (mean $A_{462} 0.546 \pm 0.148$ vs $0.178 \pm 0.008$, respectively; values are means of three independent experiments).

\section{Mutation in dnaK alters survival of $S$. aureus in vivo}

To determine the role of $d n a K$ in $S$. aureus pathogenesis, mice were injected intraperitoneally with a mixture of wildtype COL and dnaK mutant bacteria. In these studies, the $d n a K$ mutant fraction was deliberately kept at a higher level than the wild-type $S$. aureus to determine subtle changes in the ability of the mutant to survive in vivo. The infected mice were killed at 4,8 and $30 \mathrm{~h}$ after injection. No visible abscess was detected in any of the mice, and the bacterial cell number [total c.f.u. $(\mathrm{g} \text { tissue })^{-1}$ ] showed a gradual decrease with time (Fig. 6a). Interestingly, the fraction of $d n a K$ mutant cells recovered from the spleen and liver in infected mice decreased with time; however, the fraction of wild-type cells increased with time (Fig. 6b, c). Since both types of bacteria were gradually removed, the increased recovery of the wild-type cells compared with the dnaK mutant cells is suggestive of a role for DnaK in survival of S. aureus in vivo, rather than it being a mere advantage of growth of the wild-type compared with the dnaK mutant at $37{ }^{\circ} \mathrm{C}$.

\section{DISCUSSION}

Despite $S$. aureus being one of the most stress-tolerant bacterial pathogens, the mechanism of its adaptation to stress remains incompletely understood. Heat-stress tolerance is important for bacterial pathogens, as it signals a possible host environment, and helps the organism to prepare against the host immune onslaught. A locus comprising five genes ( $h r c A-g r p E-d n a K-d n a J-p r m A)$ encoding proteins that are synthesized in elevated amounts subsequent to sublethal heat stress has been identified (Ohta et al., 1994). The first gene of this locus encodes a protein HrcA, which, under normal growth conditions, negatively regulates the expression of genes in this locus. The subsequent three genes of this locus ( $g r p E$, dnaK and $d n a J)$ encode proteins that function as major proteinfolding machinery under stress conditions that cause aggregation and unfolding of proteins, and these are collectively referred to as the DnaK system (Mogk et al., 1999; Winter \& Jakob, 2004). DnaK cycles between an ATP-DnaK state (low-affinity state) and an ADP-DnaK state (high-affinity state). DnaJ brings unfolded proteins to DnaK, and this leads to the hydrolysis of ATP bound to DnaK, leading to a conformational change to its high-affinity state. The unfolded protein remains bound to DnaK-ADP until a favourable physiological state is regained. GrpE, in turn, functions as a nucleotide-exchange factor, and promotes dissociation of ADP from DnaK for
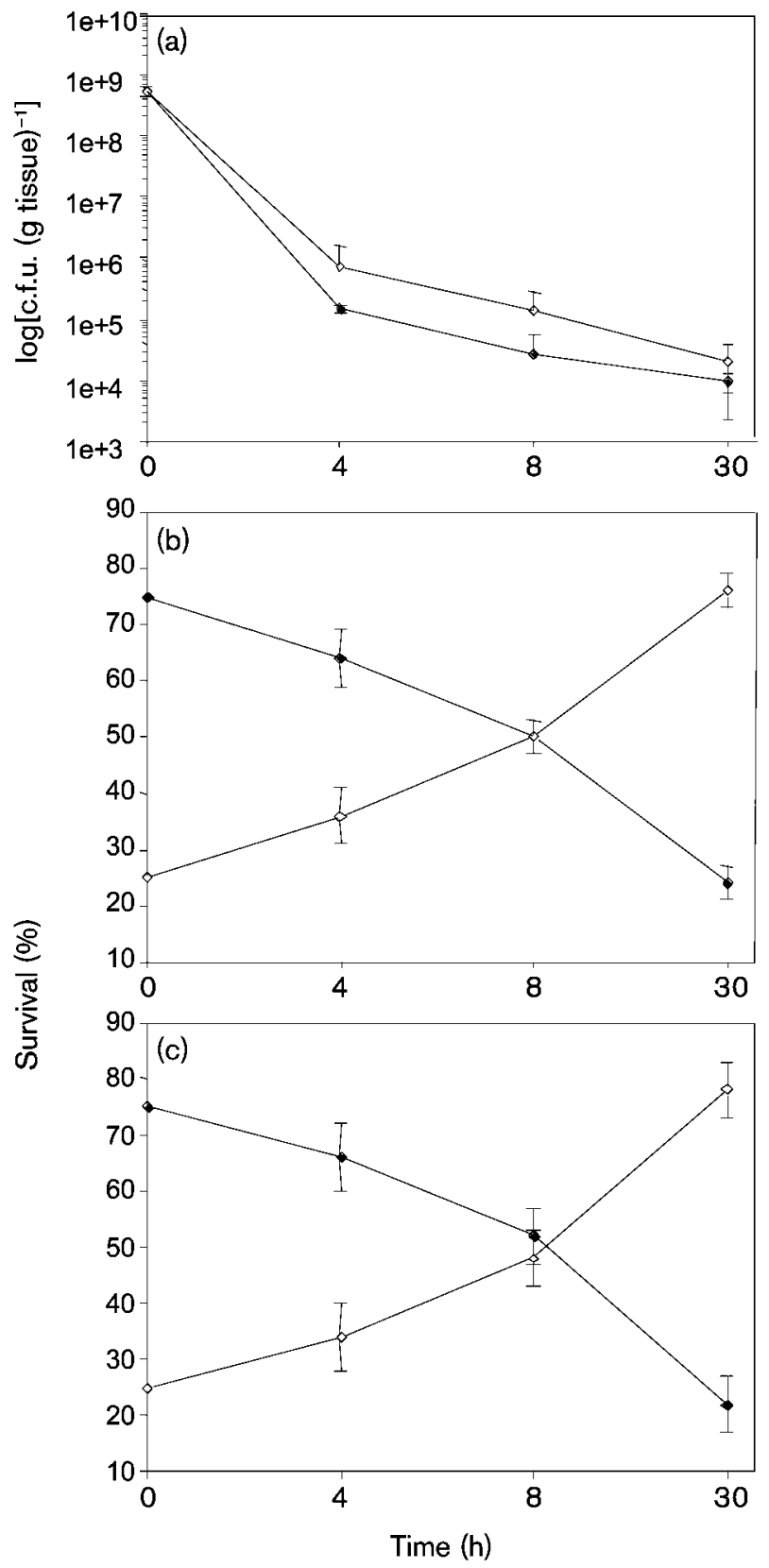

Fig. 6. Survival of the dnaK mutant and the isogenic wild-type $S$. aureus strain $\mathrm{COL}$ in the mouse model. Approximately $1.0 \times 10^{8}$ c.f.u. (24\% wild-type, and $76 \%$ dnaK mutant) were injected intraperitoneally into mice. At each time point of 4,8 and $30 \mathrm{~h}$ post-injection, three mice were killed. (a) Total number of bacteria recovered from murine livers $(\circlearrowleft)$ and spleens $(\bigcirc)$ at different time points postinfection. (b, c) Percentage survival of the dnaK mutant ( $)$ and the isogenic wild-type strain $(\bigcirc)$ recovered from infected liver and spleen, respectively. The points represent mean values (three replicates); error bars represent SEM.

ATP (Harrison, 2003; Liberek et al., 1991; McCarty et al., 1995; Winter \& Jakob, 2004). Thus, all three proteins are essential for the DnaK system to be functional. 
To study the physiological roles of the DnaK system in $S$. aureus, a dnaK deletion mutant was constructed. Insertional inactivation of the dnaK gene slowed the growth of $S$. aureus at $37^{\circ} \mathrm{C}$ (Fig. 3b), and a temperature of $43{ }^{\circ} \mathrm{C}$ was observed to be lethal for the mutant, but not for the wild-type S. aureus (Fig. 3c). These observations are consistent with findings in Bac. subtilis, E. coli, Brucella suis, Listeria monocytogenes and other bacterial species, where inactivation of $d n a K$ has been shown to result in poor growth at higher temperatures (Bukau \& Walker, 1990; Hanawa et al., 1999; Kohler et al., 2002; Schulz et al., 1995). In addition to heat, the DnaK system has also been implicated to have a role in other stress conditions, such as ethanol, low pH, salt and oxidative stress (Mogk et al., 1998; Echave et al., 2002; Periago et al., 2002). However, no difference in response to ethanol, acid, alkali or osmotic stress was observed in the case of a dnaK mutant compared with the wild-type $S$. aureus strain COL (data not shown). Interestingly, a dnaK mutant of the S. aureus strain 8325-4, which is defective in SigB (Kullik et al., 1998), was more sensitive to acid stress compared with its isogenic wild-type (data not shown). This response, however, was not observed in the case of the dnaK mutants of S. aureus strains SH1000 and COL (data not shown). S. aureus strain SH1000 is a derivative of strain 8325-4, in which the SigB defect has been corrected (Horsburgh et al., 2002). Additional stress response defects in a dnaK mutant of $S$. aureus strain 8325-4 are probably suggestive of a coordination of various staphylococcal stress factors in dealing with adverse environmental conditions.

Interestingly, mutation in $d n a K$ led to significant impairment in the oxidative stress response of the mutant compared to the wild-type $S$. aureus strain COL. Oxidative stress is known to cause lethal damage to cellular DNA, lipids and proteins. In the case of proteins, oxidative stress leads to carbonylation of amino acids and oxidation of methionine and cysteine-bound sulfur atoms (Requena et al., 2001; Stadtman et al., 2003), and this may lead to protein unfolding (Berlett \& Stadtman, 1997). This study suggests that functional DnaK protein refolding machinery is critical for the staphylococcal oxidative stress response. There was no apparent induction in the expression of the dnaK locus under the conditions of oxidative stress (Fig. 2, lane 3). This suggests that the basal level production of DnaK is sufficient to provide protection for cells against oxidative damage. Similar results have been reported in Bru. suis, where DnaK has been shown to be important in the resistance of the organism to oxidative stress, as well as to acidic $\mathrm{pH}$ (Kohler et al., 2002). In L. monocytogenes however, a dnaK mutant has been shown to be more susceptible to acidic conditions than the wild-type strain, but not more susceptible to oxidative stress (Hanawa et al., 1999).

The mutation in dnaK increased the susceptibility of meticillin-resistant strain $\mathrm{COL}$ to the cell-wall-active antibiotics oxacillin and meticillin (Table 2). In the case of the meticillin-susceptible strain SH1000, deletion of dnaK did not reduce the oxacillin MIC, but it led to a significantly reduced survival after oxacillin treatment. Challenge of meticillin-susceptible $S$. aureus by cell wallactive antibiotics induces a cell wall stress stimulon (Kuroda et al., 2003; Utaida et al., 2003; Wilkinson et al., 2005). Genes induced include genes encoding enzymes involved in cell-wall biosynthesis, and molecular chaperones and proteases. A number of these genes are controlled by the VraSR two-component regulatory system (Kuroda et al., 2003). Inactivation of VraSR results in reduced oxacillin MICs in meticillin-resistant S. aureus (BoyleVavra et al., 2006; Gardete et al., 2006). VraSR has been proposed to be a sentinel sensing perturbations in peptidoglycan biosynthesis, functioning to control the expression of genes involved in generation of a resistance phenotype. The decreased oxacillin MIC of the dnaK mutant of strain COL, and the decreased persistence of the dnaK mutant of strain SH1000, suggest that protein damage does occur as a result of challenge with cell-wallactive antibiotics, and that DnaK plays a role in dealing with these damaged proteins.

Surprisingly, the $d n a K$ mutants of $S$. aureus produced fewer carotenoids during growth on TSA plates, and also in liquid culture, compared with their wild-type counterparts. Reduced pigmentation was more evident in case of the $S$. aureus strain SH1000. Pale yellow orange colonies were observed for the dnaK mutant, compared with bright golden-yellow colonies for the wild-type cells, on TSA plates. Although it is unclear how the DnaK deletion is affecting pigmentation in the $S$. aureus mutant cells, a recent study has shown that $S$. aureus mutants with disrupted carotenoid biosynthesis are more susceptible to oxidative killing and killing by neutrophils, and are less pathogenic (Liu et al., 2005).

When the dnaK mutants of $S$. aureus were tested for their survival in mice, the mutants showed significantly reduced survival compared with their wild-type counterpart. Several features of the dnaK mutant may account for this reduced survival. Their susceptibility to oxidative stress may account for their increased vulnerability to the host phagocytic cells. Reduced pigmentation also may, in part, be responsible for reduced survival in a host, in view of the findings of a correlation between carotenoid production and staphylococcal pathogenesis (Liu et al., 2005). Additionally, autolysins have also been demonstrated to be important in staphylococcal pathogenesis (Mani et al., 1994). At this point, although it is debatable whether DnaK should be viewed as a staphylococcal virulence factor, this study suggests that its presence confers an advantage during the initial stages of infection in a host.

In conclusion, inactivation of $d n a K$ in S. aureus impairs the growth and survival of $S$. aureus at elevated temperatures, under oxidative stress, in the presence of cell-wall-active antibiotics and inside a host. Mutation also impairs carotenoid production and cell autolysis. 


\section{ACKNOWLEDGEMENTS}

This work was supported by start-up funds from the Kirksville College of Osteopathic Medicine (KCOM) to V.K.S., a grant from KCOM Biomedical Sciences Graduate Program to L.S.J., grant AI43970 to B. J. W., and grant GM071363 to R. K. J. from the National Institutes of Health.

\section{REFERENCES}

Abramoff, M. D., Magelhaes, P. J. \& Ram, S. J. (2004). Image processing with ImageJ. Biophot Int 11, 36-42.

Anderson, K. L., Roberts, C., Disz, T., Vonstein, V., Hwang, K., Overbeek, R., Olson, P. D., Projan, S. J. \& Dunman, P. M. (2006). Characterization of the Staphylococcus aureus heat shock, cold shock, stringent, and SOS responses and their effects on log-phase mRNA turnover. J Bacteriol 188, 6739-6756.

Augustin, J., Rosenstein, R., Wieland, B., Schneider, U., Schnell, N., Engelke, G., Entian, K. D. \& Gotz, F. (1992). Genetic analysis of epidermin biosynthetic genes and epidermin-negative mutants of Staphylococcus epidermidis. Eur J Biochem 204, 1149-1154.

Bal, A. M. \& Gould, I. M. (2005). Antibiotic resistance in Staphylococcus aureus and its relevance in therapy. Expert Opin Pharmacother 6, 2257-2269.

Berlett, B. S. \& Stadtman, E. R. (1997). Protein oxidation in aging, disease, and oxidative stress. J Biol Chem 272, 20313-20316.

Boyle-Vavra, S., Yin, S. \& Daum, R. S. (2006). The VraS/VraR twocomponent regulatory system required for oxacillin resistance in community-acquired methicillin-resistant Staphylococcus aureus. FEMS Microbiol Lett 262, 163-171.

Bukau, B. \& Walker, G. C. (1990). Mutations altering heat shock specific subunit of RNA polymerase suppress major cellular defects of E. coli mutants lacking the DnaK chaperone. EMBO J 9, 4027-4036.

Chastanet, A., Fert, J. \& Msadek, T. (2003). Comparative genomics reveal novel heat shock regulatory mechanisms in Staphylococcus aureus and other Gram-positive bacteria. Mol Microbiol 47, 1061-1073.

Chatterjee, I., Becker, P., Grundmeier, M., Bischoff, M., Somerville, G. A., Peters, G., Sinha, B., Harraghy, N., Proctor, R. A. \& Herrmann, M. (2005). Staphylococcus aureus $\mathrm{ClpC}$ is required for stress resistance, aconitase activity, growth recovery, and death. J Bacteriol 187, 4488-4496.

Checa, S. K. \& Viale, A. M. (1997). The 70-kDa heat-shock protein/ DnaK chaperone system is required for the productive folding of ribulose-biphosphate carboxylase subunits in Escherichia coli. Eur J Biochem 248, 848-855.

Chopra, I. (2003). Antibiotic resistance in Staphylococcus aureus: concerns, causes and cures. Expert Rev Anti Infect Ther 1, 45-55.

Craig, E. A. (1985). The heat shock response. CRC Crit Rev Biochem 18, 239-280.

Cui, L., Iwamoto, A., Lian, J. Q., Neoh, H. M., Maruyama, T., Horikawa, Y. \& Hiramatsu, K. (2006). Novel mechanism of antibiotic resistance originating in vancomycin-intermediate Staphylococcus aureus. Antimicrob Agents Chemother 50, 428-438.

Derre, I., Rapoport, G. \& Msadek, T. (1999). CtsR, a novel regulator of stress and heat shock response, controls $c l p$ and molecular chaperone gene expression in Gram-positive bacteria. Mol Microbiol 31, $117-131$.

Diamant, S. \& Goloubinoff, P. (1998). Temperature-controlled activity of DnaK-DnaJ-GrpE chaperones: protein-folding arrest and recovery during and after heat shock depends on the substrate protein and the GrpE concentration. Biochemistry 37, 9688-9694.

Echave, P., Esparza-Ceron, M. A., Cabiscol, E., Tamarit, J., Ros, J., Membrillo-Hernandez, J. \& Lin, E. C. (2002). DnaK dependence of mutant ethanol oxidoreductases evolved for aerobic function and protective role of the chaperone against protein oxidative damage in Escherichia coli. Proc Natl Acad Sci U S A 99, 4626-4631.

Frees, D., Qazi, S. N., Hill, P. J. \& Ingmer, H. (2003). Alternative roles of ClpX and ClpP in Staphylococcus aureus stress tolerance and virulence. Mol Microbiol 48, 1565-1578.

Frees, D., Chastanet, A., Qazi, S., Sorensen, K., Hill, P., Msadek, T. \& Ingmer, H. (2004). Clp ATPases are required for stress tolerance, intracellular replication and biofilm formation in Staphylococcus aureus. Mol Microbiol 54, 1445-1462.

Gardete, S., Wu, S. W., Gill, S. \& Tomasz, A. (2006). Role of VraSR in antibiotic resistance and antibiotic-induced stress response in Staphylococcus aureus. Antimicrob Agents Chemother 50, 3424-3434.

Gill, S. R., Fouts, D. E., Archer, G. L., Mongodin, E. F., Deboy, R. T., Ravel, J., Paulsen, I. T., Kolonay, J. F., Brinkac, L. \& other authors (2005). Insights on evolution of virulence and resistance from the complete genome analysis of an early methicillin-resistant Staphylococcus aureus strain and a biofilm-producing methicillinresistant Staphylococcus epidermidis strain. J Bacteriol 187, 2426-2438.

Gutierrez, J. A., Crowley, P. J., Brown, D. P., Hillman, J. D., Youngman, P. \& Bleiweis, A. S. (1996). Insertional mutagenesis and recovery of interrupted genes of Streptococcus mutans by using transposon Tn917: preliminary characterization of mutants displaying acid sensitivity and nutritional requirements. J Bacteriol 178, 4166-4175.

Hanawa, T., Fukuda, M., Kawakami, H., Hirano, H., Kamiya, S. \& Yamamoto, T. (1999). The Listeria monocytogenes DnaK chaperone is required for stress tolerance and efficient phagocytosis with macrophages. Cell Stress Chaperones 4, 118-128.

Harrison, C. (2003). GrpE, a nucleotide exchange factor for DnaK. Cell Stress Chaperones 8, 218-224.

Hartl, F. U. (1996). Molecular chaperones in cellular protein folding. Nature 381, 571-579.

Helmann, J. D., Wu, M. F., Kobel, P. A., Gamo, F. J., Wilson, M., Morshedi, M. M., Navre, M. \& Paddon, C. (2001). Global transcriptional response of Bacillus subtilis to heat shock. J Bacteriol 183, 7318-7328.

Homuth, G., Masuda, S., Mogk, A., Kobayashi, Y. \& Schumann, W. (1997). The dnaK operon of Bacillus subtilis is heptacistronic. $J$ Bacteriol 179, 1153-1164.

Horsburgh, M. J., Aish, J. L., White, I. J., Shaw, L., Lithgow, J. K. \& Foster, S. J. (2002). SigmaB modulates virulence determinant expression and stress resistance: characterization of a functional $r s b U$ strain derived from Staphylococcus aureus 8325-4. J Bacteriol 184, 5457-5467.

Hubbard, T. J. \& Sander, C. (1991). The role of heat-shock and chaperone proteins in protein folding: possible molecular mechanisms. Protein Eng 4, 711-717.

Kohler, S., Ekaza, E., Paquet, J. Y., Walravens, K., Teyssier, J., Godfroid, J. \& Liautard, J. P. (2002). Induction of dnaK through its native heat shock promoter is necessary for intramacrophagic replication of Brucella suis. Infect Immun 70, 1631-1634.

Korch, S. B. \& Hill, T. M. (2006). Ectopic overexpression of wild-type and mutant hipA genes in Escherichia coli: effects on macromolecular synthesis and persister formation. J Bacteriol 188, 3826-3836.

Kreiswirth, B. N., Lofdahl, S., Betley, M. J., O’Reilly, M., Schlievert, P. M., Bergdoll, M. S. \& Novick, R. P. (1983). The toxic shock syndrome exotoxin structural gene is not detectably transmitted by a prophage. Nature 305, 709-712. 
Kullik, I., Giachino, P. \& Fuchs, T. (1998). Deletion of the alternative sigma factor sigmaB in Staphylococcus aureus reveals its function as a global regulator of virulence genes. J Bacteriol 180, 4814-4820.

Kuroda, M., Ohta, T., Uchiyama, I., Baba, T., Yuzawa, H., Kobayashi, I., Cui, L., Oguchi, A., Aoki, K. \& other authors (2001). Whole genome sequencing of meticillin-resistant Staphylococcus aureus. Lancet 357, $1225-1240$.

Kuroda, M., Kuroda, H., Oshima, T., Takeuchi, F., Mori, H. \& Hiramatsu, K. (2003). Two-component system VraSR positively modulates the regulation of cell-wall biosynthesis pathway in Staphylococcus aureus. Mol Microbiol 49, 807-821.

Liberek, K., Marszalek, J., Ang, D., Georgopoulos, C. \& Zylicz, M. (1991). Escherichia coli DnaJ and GrpE heat shock proteins jointly stimulate ATPase activity of DnaK. Proc Natl Acad Sci U S A 88, 2874-2878.

Liu, G. Y., Essex, A., Buchanan, J. T., Datta, V., Hoffman, H. M., Bastian, J. F., Fierer, J. \& Nizet, V. (2005). Staphylococcus aureus golden pigment impairs neutrophil killing and promotes virulence through its antioxidant activity. J Exp Med 202, 209-215.

Lyczak, J. B., Cannon, C. L. \& Pier, G. B. (2002). Lung infections associated with cystic fibrosis. Clin Microbiol Rev 15, 194-222.

Maguire, M., Coates, A. R. \& Henderson, B. (2002). Chaperonin 60 unfolds its secrets of cellular communication. Cell Stress Chaperones 7 , 317-329.

Mani, N., Baddour, L. M., Offutt, D. Q., Vijaranakul, U., Nadakavukaren, M. J. \& Jayaswal, R. K. (1994). Autolysis-defective mutant of Staphylococcus aureus: pathological considerations, genetic mapping, and electron microscopic studies. Infect Immun 62, 1406-1409.

Marshall, J. H. \& Wilmoth, G. J. (1981). Pigments of Staphylococcus aureus, a series of triterpenoid carotenoids. J Bacteriol 147, 900-913.

McCarty, J. S., Buchberger, A., Reinstein, J. \& Bukau, B. (1995). The role of ATP in the functional cycle of the DnaK chaperone system. J Mol Biol 249, 126-137.

Mead, D. A., Szczesna-Skorupa, E. \& Kemper, B. (1986). Singlestranded DNA 'blue' T7 promoter plasmids: a versatile tandem promoter system for cloning and protein engineering. Protein Eng 1, 67-74.

Michel, A., Agerer, F., Hauck, C. R., Herrmann, M., Ullrich, J., Hacker, J. \& Ohlsen, K. (2006). Global regulatory impact of ClpP protease of Staphylococcus aureus on regulons involved in virulence, oxidative stress response, autolysis, and DNA repair. J Bacteriol 188, 5783-5796.

Mogk, A., Völker, A., Engelmann, S., Hecker, M., Schumann, W. \& Völker, U. (1998). Nonnative proteins induce expression of the Bacillus subtilis CIRCE regulon. J Bacteriol 180, 2895-2900.

Mogk, A., Tomoyasu, T., Goloubinoff, P., Rudiger, S., Roder, D., Langen, H. \& Bukau, B. (1999). Identification of thermolabile Escherichia coli proteins: prevention and reversion of aggregation by DnaK and ClpB. EMBO J 18, 6934-6949.

Novick, R. P. (1991). Genetic systems in staphylococci. Methods Enzymol 204, 587-636.

Ohta, T., Saito, K., Kuroda, M., Honda, K., Hirata, H. \& Hayashi, H. (1994). Molecular cloning of two new heat shock genes related to the hsp70 genes in Staphylococcus aureus. J Bacteriol 176, 4779-4783.

Periago, P. M., van Schaik, W., Abee, T. \& Wouters, J. A. (2002). Identification of proteins involved in the heat stress response of Bacillus cereus ATCC 14579. Appl Environ Microbiol 68, 3486-3495.

Pfeltz, R. F., Singh, V. K., Schmidt, J. L., Batten, M. A., Baranyk, C. S., Nadakavukaren, M. J., Jayaswal, R. K. \& Wilkinson, B. J. (2000). Characterization of passage-selected vancomycin-resistant Staphylococcus aureus strains of diverse parental backgrounds. Antimicrob Agents Chemother 44, 294-303.
Projan, S. J. \& Novick, R. P. (1997). The molecular basis of pathogenicity. In The Staphylococci in Human Disease, pp. 55-81. Edited by K. B. Crossley \& G. L. Archer. New York: Churchill Livingstone.

Qoronfleh, M. W., Streips, U. N. \& Wilkinson, B. J. (1990). Basic features of the staphylococcal heat shock response. Antonie Van Leeuwenhoek 58, 79-86.

Qoronfleh, M. W., Weraarchakul, W. \& Wilkinson, B. J. (1993). Antibodies to a range of Staphylococcus aureus and Escherichia coli heat shock proteins in sera from patients with $S$. aureus endocarditis. Infect Immun 61, 1567-1570.

Qoronfleh, M. W., Bortner, C. A., Schwartzberg, P. \& Wilkinson, B. J. (1998). Enhanced levels of Staphylococcus aureus stress protein GroEL and DnaK homologs early in infection of human epithelial cells. Infect Immun 66, 3024-3027.

Requena, J. R., Chao, C. C., Levine, R. L. \& Stadtman, E. R. (2001). Glutamic and aminoadipic semialdehydes are the main carbonyl products of metal-catalyzed oxidation of proteins. Proc Natl Acad Sci U S A 98, 69-74.

Schenk, S. \& Laddaga, R. A. (1992). Improved method for electroporation of Staphylococcus aureus. FEMS Microbiol Lett 73, 133-138.

Schito, G. C. (2006). The importance of the development of antibiotic resistance in Staphylococcus aureus. Clin Microbiol Infect 12 (Suppl. 1), $3-8$.

Schulz, A. \& Schumann, W. (1996). hrcA, the first gene of the Bacillus subtilis dnaK operon encodes a negative regulator of class I heat shock genes. J Bacteriol 178, 1088-1093.

Schulz, A., Tzschaschel, B. \& Schumann, W. (1995). Isolation and analysis of mutants of the dnaK operon of Bacillus subtilis. Mol Microbiol 15, 421-429.

Schwan, W. R., Lehmann, L. \& McCormick, J. (2006). Transcriptional activation of the Staphylococcus aureus putP gene by low-prolinehigh-osmotic conditions and during infection of murine and human tissues. Infect Immun 74, 399-409.

Singh, V. K. \& Moskovitz, J. (2003). Multiple methionine sulfoxide reductase genes in Staphylococcus aureus: expression of activity and roles in tolerance of oxidative stress. Microbiology 149, 2739-2747.

Singh, V. K., Jayaswal, R. K. \& Wilkinson, B. J. (2001a). Cell wall-active antibiotic induced proteins of Staphylococcus aureus identified using a proteomic approach. FEMS Microbiol Lett 199, 79-84.

Singh, V. K., Moskovitz, J., Wilkinson, B. J. \& Jayaswal, R. K. (2001b). Molecular characterization of a chromosomal locus in Staphylococcus aureus that contributes to oxidative defence and is highly induced by the cell-wall-active antibiotic oxacillin. Microbiology 147, 3037-3045.

Stadtman, E. R., Moskovitz, J. \& Levine, R. L. (2003). Oxidation of methionine residues of proteins: biological consequences. Antioxid Redox Signal 5, 577-582.

Stewart, P. S. (2002). Mechanisms of antibiotic resistance in bacterial biofilms. Int J Med Microbiol 292, 107-113.

Sutherland, R. \& Rolinson, G. N. (1964). Characteristics of methicillin-resistant staphylococci. J Bacteriol 87, 887-899.

Talaat, A. M., Howard, S. T., Hale, W. T., Lyons, R., Garner, H. \& Johnston, S. A. (2002). Genomic DNA standards for gene expression profiling in Mycobacterium tuberculosis. Nucleic Acids Res 30, e104.

Utaida, S., Dunman, P. M., Macapagal, D., Murphy, E., Projan, S. J., Singh, V. K., Jayaswal, R. K. \& Wilkinson, B. J. (2003). Genome-wide transcriptional profiling of the response of Staphylococcus aureus to cell-wall-active antibiotics reveals a cell-wall-stress stimulon. Microbiology 149, 2719-2732. 
Walter, S. \& Buchner, J. (2002). Molecular chaperones - cellular machines for protein folding. Angew Chem Int Ed Engl 41, 1098-1113.

Wilkinson, B. J., Muthaiyan, A. \& Jayaswal, R. K. (2005). The cell wall stress stimulon of Staphylococcus aureus and other Gram-positive bacteria. Curr Med Chem Anti-Infect Agents 4, 259-276.

Winter, J. \& Jakob, U. (2004). Beyond transcription - new mechanisms for the regulation of molecular chaperones. Crit Rev Biochem Mol Biol 39, 297-317.
Yanisch-Perron, C., Vieira, J. \& Messing, J. (1985). Improved M13 phage cloning vectors and host strains: nucleotide sequences of the M13mp18 and pUC19 vectors. Gene 33, 103-119.

Yura, T., Kanemori, M. \& Morita, M. T. (2000). The heat shock response: regulation and function. In Bacterial Stress Response, pp. 318. Edited by G. Storz \& R. Hengge-Aronis. Washington, DC: American Society for Microbiology.

Edited by: T. Msadek 